\title{
Milk and cheese fatty acid profiles in Alpine goat fed green maize forage
}

\author{
F. Pajor ${ }^{1}$, O. Galló and P. Póti \\ Szent István University, Institute of Animal Husbandry, H-2103, Gödöllö, Páter Károly 1, Hungary
}

KEY WORDS: goat, green maize, lucerne, milk, cheese, fatty acids

Received: 7 June 2012

Revised: 25 July 2013

Accepted: 2 September 2013

${ }^{1}$ Corresponding author: e-mail:

pajor.ferenc@mkk.szie.hu

\begin{abstract}
Twenty lactating Alpine goats were randomly allocated to two treatment groups to investigate the effect of feeding green maize on the fatty acid profile of milk and cheese. The control goats were fed lucerne hay ad libitum; the other group was fed green maize plants ad libitum; additionally, all animals received $350 \mathrm{~g}$ per day per goat concentrate of the same composition. The green maize diet considerably increased the rumenic acid concentration in milk $(0.44 \%$ vs $0.60 \% ; P<0.01)$ and in cheese $(0.46 \%$ vs $0.78 \% ; P<0.01)$ and increased the n-3 fatty acids in milk $(0.55 \%$ vs $1.05 \%$; $P<0.001)$ and in cheese $(0.62 \%$ vs $1.04 \% ; P<0.01)$. In addition, the $\mathrm{n}-6 / \mathrm{n}-3$ ratio was also more favourable in the experimental group (6.04 vs 1.88 in milk, $P<0.01 ; 4.72$ vs 2.43 in cheese, $P<0.001)$. It is concluded that the milk and cheese from goats fed green maize are more beneficial in human nutrition than the milk produced by animals fed lucerne hay.
\end{abstract}

\section{Introduction}

The typical modern diet is characterized by a high intake of $n-6$ polyunsaturated fatty acids (PUFA) and low intake of n-3 PUFA. A high ratio of $n-6 / n-3$ PUFA is a risk factor for coronary heart disease, especially formation of blood clots leading to heart attacks (Enser et al., 1998). The recommended intake is an n- $6 / \mathrm{n}-3$ ratio of less than 4 (Simopoulos, 2004). Another beneficial compound of milk is rumenic acid (c9t11CLA isomer). It has a range of positive health properties such as anticarcinogenic (Ip et al., 1991) and antiatherogenic effects (Nicolosi al., 1997). Pasture diets have been associated with a high content of conjugated linoleic acid and n-3 fatty acids of milk fat, because grass is rich in $\alpha$-linolenic acid (Cabiddu et al., 2005). Although a number of studies on the effects of pasture and, in some cases, green forages (Addis et al., 2005) on milk fatty acids, especially on rumenic acid content, have been conducted in ruminant species, literature reports on goat milk and cheese are rather limited (Tsiplakou et al., 2006; Galina et al., 2007; Pajor et al., 2009) compared with those on cows. Unfortunately, during the summer, herbage quantity and quality parameters (e.g., protein content and energy concentration) of pastures decline due to the reproduction phase of grass, consequently, animals need to be provided some additional feed, which in practice means hay-based feeding. In this way, decreases in the milk rumenic acid and n-3 fatty acid contents are observed (e.g., Tsiplakou et al., 2006). One of the possible ways of manipulating the fatty acid contents is by feeding harvested green forages in confinement. We hypothesized that the goat milk fatty acid profile could be improved when green maize was fed instead of a hay-based diet. It is well known that this plant has a high crop yield 
and energy content but changes markedly during the vegetation period. Moreover, it is widely cultivated throughout the world and easily fits into green fodder production systems of small-scale farms. Nonetheless, little is still known about the green maize fatty acid contents and the effect of green maize on milk fatty acid composition. The aim of this study was to investigate the effect of feeding green maize on the fatty acid profile of goat milk and cheese.

\section{Material and methods}

\section{Experimental animals}

The study was carried out in a typical Hungarian goat small enterprise farm on the Great Plain (Kiskunfelegyhaza, Bács-Kiskun County, Hungary). Twenty Alpine goats [average DIM (days in milking) $=110 \pm 6.9$ days] were randomly allocated to two treatment groups. The groups were balanced for parity and time of kidding. The diets were adjusted to the NRC (2007) recommendations of energy and protein requirements for dairy goats (body weight 60 $\mathrm{kg} ; 2.0 \mathrm{~kg}$ of milk per day). The control group ( $\mathrm{n}=10$ goats) was kept indoors and fed ad libitum medium quality lucerne hay (crude protein $15.2 \%$ of dry matter), the goats from the other group $(n=10)$ were kept indoors and fed ad libitum harvested green maize plants. Additionally, all goats were fed on average $350 \mathrm{~g}$ concentrate per goat daily ( $40 \%$ barley, $20 \%$ wheat, $20 \%$ maize and $20 \%$ wheat bran). Both groups had the same composition of the grain mix, which was given twice a day in equal amounts. Daily feed intake (denoted as kg of dry matter) and refusals of forages were measured. A commercial vitamin $\left(\mathrm{A}, \mathrm{D}_{3}, \mathrm{E}\right)$ and trace-mineralized salt block was provided free choice to goats.

The investigation was started in early July and lasted 5 weeks, which encompassed the first 3 weeks as the period of adaptation to the diet and the last 2 weeks as the experimental period. Green maize (vegetation growth stage: beginning of tasseling) was harvested and offered once daily at 8.00 a.m. into self-unloading cages. The samples $(\mathrm{n}=3$ per forage) of the green maize, lucerne hay and grain mix were collected during the last experimental week. Ingredients, chemical composition, intake, and fatty acid profile of diets are shown in Table 1.

The individual milk samples were collected from animals once a week during the first 2 weeks of the experimental period at $6.00 \mathrm{a} . \mathrm{m}$. and $6.00 \mathrm{p} . \mathrm{m}$., the milk samples were frozen and stored at $-20^{\circ} \mathrm{C}$ until further analysis. Before laboratory investigation, milk samples gathered twice a day were combined for analysis of chemical composition.
Table 1. Ingredients, daily intake, chemical composition and fatty acid profile of the diets

\begin{tabular}{lcc}
\hline Component & $\begin{array}{c}\text { Control } \\
\text { diet }\end{array}$ & $\begin{array}{l}\text { Experimental } \\
\text { diet }\end{array}$ \\
\hline Ingredients, \% in DM & & \\
green maize & - & 86.0 \\
lucerne hay & 85.5 & - \\
concentrate mix & 14.5 & 14.0 \\
daily intake, kg in DM & 2.13 & 2.21 \\
Chemical composition, g kg $^{-1}$ DM & & \\
NEl, MJ & 5.69 & 6.20 \\
crude protein & 150.05 & 118.56 \\
MPE 1 & 88.11 & 76.06 \\
MPN 2 & 106.47 & 85.22 \\
crude fat & 18.46 & 25.04 \\
crude fibre & 303.22 & 221.88 \\
Crude ash & 63.44 & 65.11 \\
N-free extractives & 465.53 & 571.45 \\
Fatty acids, \% & & \\
C12:0 & 0.36 & 0.66 \\
C14:0 & 0.93 & 0.78 \\
C14:1c9 & 0.05 & 0.04 \\
C16:0 & 30.12 & 27.79 \\
C16:1c9 & 1.61 & 0.86 \\
C18:0 & 4.43 & 2.86 \\
C18:1c9 & 6.36 & 5.95 \\
C18:2n-6 & 25.59 & 28.4 \\
C18:3n-3 & 19.22 & 27.03 \\
\hline
\end{tabular}

${ }^{1}$ MPE - metabolizable protein - energy; ${ }^{2}$ MPN - metabolizable protein - nitrogen

\section{Cheese processing}

A total of $20 \mathrm{~kg}$ of goat milk per group was processed into cheese (about $200 \mathrm{~g}$ per cheese) at 2, 5, 8,11 and 14 days throughout the experimental period. The soft cheese was processed by the description shown in Table 2. One soft cheese per batch from each group was taken for chemical analysis. The cheese samples were collected after a 1-weekripening period. Samples were analysed for fatty acid content as described below.

\section{Table 2. Description of soft cheese manufacturing}

\begin{tabular}{|c|c|}
\hline \multicolumn{2}{|c|}{ Characteristic of processing } \\
\hline 1 & Raw milk heating up to $31^{\circ} \mathrm{C}$ \\
\hline 2 & $\begin{array}{l}\text { Addition bacterial culture }(1.5 \%) \text { and } \mathrm{CaCl}_{2}\left(15 \mathrm{~g} \cdot 100 \mathrm{I} \mathrm{milk}^{-1}\right) \text {, } \\
20 \text { min incubation }\end{array}$ \\
\hline 3 & Addition bacterial commercial rennet, 60 min coagulation time \\
\hline 4 & Scooping and draining (wheat size) \\
\hline 5 & Post heating up to $35^{\circ} \mathrm{C}, 20 \mathrm{~min}$ \\
\hline 6 & Formation of cheeses and moulding in block of $\sim 200-300 \mathrm{~g}$ \\
\hline 7 & Press: $12 \mathrm{~h}$, pressure: self weight, turning: $3 \mathrm{x}$ \\
\hline 8 & Salt bath: duration: $1 \mathrm{~h}, \mathrm{cc}: 22 \%$, temperature: $15^{\circ} \mathrm{C}$ \\
\hline 9 & Ripen: $17-18^{\circ} \mathrm{C}, 85 \%$ relative humidity for 1 week \\
\hline
\end{tabular}




\section{Chemical analysis}

The forage samples $(n=3)$ were analysed for dry matter, crude protein, crude fat, crude fibre, crude ash and metabolizable protein according to the procedure of the Hungarian Feed Codex (2004).

Fat, protein, lactose and total solids without fat contents of milk were determined using a MilkoScan device (Combi Foss 5000 apparatus, Foss Electric, Denmark).

The milk and cheese fat were dissolved in a sodium hydroxide-methanol solution and re-esterified to methyl esters according to the AOAC (1990) method using boron trifluoride $\left(\mathrm{BF}_{3}\right)$. Methyl esters of fatty acids were determined by gas chromatography using a Shimadzu GC 2010 apparatus (Japan) with a flame ionization detector (FID) and column (CP-SIL-88, $100 \mathrm{~m} \times 0.25 \mathrm{~mm} \times 0.2 \mu \mathrm{m})$. The split injection ratio was 50:1. The column oven temperature was held at $80^{\circ} \mathrm{C}$ for $0 \mathrm{~min}$, then programmed at a rate of $2.5^{\circ} \mathrm{C} \cdot \mathrm{min}^{-1}$ up to $205^{\circ} \mathrm{C}$ and held for $20 \mathrm{~min}$ and then increased again to $225^{\circ} \mathrm{C}$ at $10^{\circ} \mathrm{C} \cdot \mathrm{min}^{-1}$, and held for $5 \mathrm{~min}$. The injector and detector temperatures were $270^{\circ} \mathrm{C}$ and $300^{\circ} \mathrm{C}$, respectively. Helium was used as the carrier gas, applying a flow rate $28 \mathrm{~cm} \cdot \mathrm{s}^{-1}$. Peaks were identified on the basis of the retention times of standard methyl esters of individual fatty acids (Mixture Me 100, Larodan Fine Chemicals AB, Sweden). The proportions of the individual acids were calculated by the ratio of their peak area to the total area of all observed acids.

\section{Statistical analysis}

Statistical analysis was processed by the SPSS 14.0 software package (Shapiro-Wilk test for normality distribution, $\mathrm{F}$ test for equality of variances, t-test, and Welch's corrected t-test).

\section{Results}

The daily forage intake (dry matter, $\mathrm{kg}$ ) was similar between the two diets (control: $2.13 \mathrm{~kg}$, experimental: $2.21 \mathrm{~kg}$ ), but the daily milk yield during the investigation was lower $(p<0.05)$ in control goats at $2.1 \mathrm{~kg}$, compared with $2.4 \mathrm{~kg}$ milk yield for experimental goats. Milk composition was significantly affected by diet. The lucerne hay diet caused lower $(p<0.05)$ fat $\left(3.02 \mathrm{~g} \cdot 100 \mathrm{~g}^{-1}\right)$, protein $\left(2.89 \mathrm{~g} \cdot 100 \mathrm{~g}^{-1}\right)$, lactose $\left(4.60 \mathrm{~g} \cdot 100 \mathrm{~g}^{-1}\right)$ and nonfat solids $\left(7.55 \mathrm{~g} \cdot 100 \mathrm{~g}^{-1}\right)$ contents compared with milk from green maize-fed goats $(3.22,2.94,4.69$ and $7.87 \mathrm{~g} \cdot 100 \mathrm{~g}^{-1}$, respectively) (data not presented in Table). Thus, the diets significantly influenced milk composition during the investigated period.
The results of fatty acid analysis of milk and cheese samples are presented in Table 3.

The green maize diet significantly increased the concentrations of short-chain fatty acids (butyric, caproic and caprylic), stearic (C18:0), $\alpha$-linolenic (C18:3), eicosapentaenoic (C20:5), docosahexaenoic (C22:6), total polyunsaturated and n-3 fatty acids, as well as significantly decreased those of lauric (C12:0), miristoleic (C14:1), palmitoleic (C16:1), linoleic (C18:2), and n-6 fatty acids in milk and cheese.

In contrast, the concentrations of capric acid (C10:0), palmitic acid (C16:0), oleic acid (C18:1), total saturated fatty acids and total monounsaturated fatty acids in milk and cheese samples did not show any significant differences during the experimental period.

In the present study, the $n-6 / n-3$ ratios equalled 6.04 and 1.88 in milk and 4.72 and 2.43 in cheese samples from animals receiving hay and green maize treatments, respectively.

Feeding green maize positively affected the concentration of rumenic acid in milk and cheese samples. In milk, the rumenic acid concentrations were $0.44 \%$ and $0.60 \%$, in cheese, $0.46 \%$ and $0.78 \%$ for the control and experimental diets, respectively.

\section{Discussion}

Feeding green maize significantly influenced the yield and composition of goat milk. A higher energy concentration, lower metabolizable protein content, as well as a slight $\mathrm{N}$ imbalance (MPNMPE) were detected in the experimental diet. Positive $\mathrm{N}$ balance is important in early lactation, but in mid-lactation on a medium milk production level, it is not crucial. The milk production, fat and protein contents were higher in goats from the experimental group. This could be a result of the higher energy concentration, as energy is provided to support protein synthesis. Nevertheless, it is well known that goat milk fat and protein contents are affected by many factors, such as diet, breed, parity and stage of lactation (Kuchtik et al., 2008; Novotna et al., 2009). Soryal et al. (2004) in Alpine goat, and Pajor et al. (2009) in Hungarian Native goat, found that feeding green fodder (pasture) slightly increased the milk fat, protein and non-fat solids compositions. Milk composition is important for breeders because it determines the composition of cheese.

The experimental feeding regime increased the concentrations of short-chain fatty acids in samples of milk and cheese. Increases in butyric, caproic and caprylic fatty acids have been observed. 
Table 3. Effect of green maize supplementation on fatty acid profile and conjugated linoleic acid isomers of goat milk and cheese (mean \pm SD), $\%$

\begin{tabular}{|c|c|c|c|c|c|c|c|c|}
\hline \multirow[b]{2}{*}{ Fatty acids } & \multicolumn{4}{|c|}{ Milk samples } & \multicolumn{4}{|c|}{ Cheese samples } \\
\hline & $\begin{array}{l}\text { control } \\
\text { diet }\end{array}$ & $\begin{array}{l}\text { experimental } \\
\text { diet }\end{array}$ & SEM & $P$ & $\begin{array}{l}\text { control } \\
\text { diet }\end{array}$ & $\begin{array}{l}\text { experimental } \\
\text { diet }\end{array}$ & SEM & $P$ \\
\hline $\mathrm{C} 4: 0$ & 0.59 & 1.58 & 0.13 & $* * *$ & 0.68 & 1.05 & 0.07 & * \\
\hline C6:0 & 1.27 & 2.24 & 0.14 & $* * *$ & 1.38 & 2.32 & 0.16 & $* * *$ \\
\hline $\mathrm{C} 8: 0$ & 2.11 & 2.83 & 0.13 & $* *$ & 2.15 & 2.63 & 0.09 & * \\
\hline C10:0 & 9.80 & 10.14 & 0.31 & N.S. & 8.70 & 9.03 & 0.11 & NS \\
\hline C12:0 & 5.47 & 4.03 & 0.31 & * & 4.89 & 3.96 & 0.17 & $* *$ \\
\hline C14:0 & 12.25 & 10.28 & 0.35 & $* *$ & 12.09 & 11.50 & 0.15 & N.S. \\
\hline C14:1c9 & 0.19 & 0.13 & 0.16 & * & 0.19 & 0.15 & 0.01 & * \\
\hline C16:0 & 32.80 & 30.77 & 0.71 & N.S. & 30.77 & 29.30 & 0.42 & NS \\
\hline C16:1c9 & 0.86 & 0.37 & 0.06 & $* * \star$ & 0.65 & 0.51 & 0.03 & $* *$ \\
\hline C18:0 & 8.23 & 11.63 & 0.60 & $* *$ & 8.28 & 11.39 & 0.61 & * \\
\hline C18:1c9 & 16.96 & 18.64 & 0.53 & N.S. & 21.91 & 22.27 & 0.17 & NS \\
\hline C18:2n-6 & 2.98 & 1.79 & 0.17 & $* * *$ & 2.62 & 2.28 & 0.07 & $*$ \\
\hline C18:3n-3 & 0.41 & 0.80 & 0.05 & $* \star *$ & 0.45 & 0.79 & 0.07 & $* *$ \\
\hline$C 20: 4 n-6$ & 0.22 & 0.12 & 0.01 & $* * *$ & 0.28 & 0.19 & 0.02 & * \\
\hline C20:5n-3 & 0.03 & 0.07 & 0.01 & $* *$ & 0.02 & 0.06 & 0.01 & $* *$ \\
\hline$C 22: 5 n-3$ & 0.09 & 0.14 & 0.01 & $* * *$ & 0.13 & 0.14 & 0.00 & NS \\
\hline C22:6n-3 & 0.02 & 0.04 & 0.00 & $* * *$ & 0.02 & 0.05 & 0.01 & $* *$ \\
\hline SCFA & 13.76 & 16.79 & 0.63 & * & 12.91 & 15.02 & 0.38 & $* *$ \\
\hline SFA & 74.71 & 75.92 & 0.61 & N.S. & 72.38 & 73.12 & 0.59 & NS \\
\hline MUFA & 20.91 & 19.13 & 0.58 & N.S. & 23.54 & 22.49 & 0.31 & NS \\
\hline PUFA & 4.38 & 4.94 & 0.13 & * & 4.08 & 4.40 & 0.07 & * \\
\hline$n-6$ & 3.23 & 1.94 & 0.18 & $* * *$ & 2.91 & 2.47 & 0.09 & * \\
\hline$n-3$ & 0.55 & 1.05 & 0.06 & $* * *$ & 0.62 & 1.04 & 0.08 & $* *$ \\
\hline$n-6 / n-3$ & 6.04 & 1.88 & 0.55 & $* * *$ & 4.72 & 2.43 & 0.42 & $* * *$ \\
\hline c9t11CLA & 0.44 & 0.60 & 0.03 & * & 0.46 & 0.78 & 0.06 & $* *$ \\
\hline t10c12CLA & 0.09 & 0.10 & 0.01 & N.S. & 0.09 & 0.11 & 0.01 & NS \\
\hline CLA, total & 0.53 & 0.70 & 0.03 & $* *$ & 0.55 & 0.89 & 0.06 & $* *$ \\
\hline c9t11CLA, \% & 82.63 & 85.35 & 0.53 & $* *$ & 83.65 & 88.16 & 1.03 & * \\
\hline
\end{tabular}

NS - non significantly difference; ${ }^{*}-p<0.05 ;{ }^{* *}-P<0.01 ;{ }^{* *}-P<0.001-$ significant differences between two groups; SCFA - short chain fatty acids $\left(\mathrm{C}_{4}-\mathrm{C}_{10}\right)$; SFA - saturated fatty acids; MUFA - monounsaturated fatty acids; PUFA - polyunsaturated fatty acids; CLA - conjugated linoleic acid

The results obtained in the present investigation differ from those diets which rich in PUFA such as linseed supplemented concentrate (Zhang et al., 2006). Higher values of polyunsaturated fatty acids from the diet inhibit de novo fatty acid synthesis in the mammary gland (Couvrer et al., 2006). This is confirmed by the decreased medium-chain fatty acid content (C12:0 and C14:0 fatty acids) due to the higher secretion of long-chain fatty acids from the blood (dilution effect; Chilliard et al., 2000). In contrast, short-chain fatty acids are not influenced by a high PUFA content, as these fatty acids are synthesized in the mammary gland from acetic acid, which originates from the rumen. These results suggest that the green forage positively affected rumen function and as well as acetic acid production.

The experimental diet significantly increased the concentrations of $\alpha$-linolenic and other $n-3$ fatty acids in milk and cheese. In our study, the green maize $\alpha$-linolenic acid concentration in total fat was
$30.7 \%$, the $n-6 / n-3$ ratio was less than 1 . Grass is also rich in $\alpha$-linolenic acid - n-3 fatty acids account for about $50 \%$ of the total fat in grass (Cabiddu et al., 2005). During drying, however, decreases in forage PUFA and n-3 fatty acid concentrations occur due to oxidation and leaf losses (Doreau and Poncet, 2000; Dewhurst et al., 2006). Moreover, because of rumen biohydrogenation, a high proportion of polyunsaturated fatty acids, such as linoleic and linolenic acid, are biohydrogenated in the rumen. Both fatty acids are hydrogenated to stearic acid: the relative percentage of C18:0 was significantly increased in green maize-fed goats $(11.63 \%$ in milk and $11.39 \%$ in cheese) compared with the control group ( $8.23 \%$ in milk, $8.28 \%$ in cheese). Nevertheless, linoleic acid (C18:2) is biohydrogenated to a smaller extent than linolenic (C18:3) acid (Lee et al., 2003). On the other hand, reduction of linoleic acid in the rumen was faster with green forage than with dried forage (Buccioni et al., 2008). On 
the basis of these factors, feeding green maize can increase the concentrations of n-3 fatty acids such as $\alpha$-linolenic acid and decrease the concentrations of n-6 fatty acids such as linoleic acid in milk and cheese. The milk and cheese from the experimental goats had a higher $\alpha$-linolenic acid content $(0.41 \%$ vs $0.80 \%$ in milk; $P<0.001 ; 0.45 \%$ vs $0.79 \%$ in cheese; $P<0.01)$. In the present study, $\mathrm{n}-6 / \mathrm{n}-3$ ratios of 6.04 and 1.88 and 4.72 and 2.43 were found for milk and cheese samples of goats that fed control and experimental diets, respectively. The low $n-6 / n-3$ ratio in the milk and cheese of goats that received green maize is in keeping with the new recommendations for human nutrition. $\alpha$-linolenic acid is the precursor of n-3 PUFAs such as eicosapentaenoic acid (EPA) $\left(\mathrm{C}_{20: 5} \mathrm{n}-3\right)$ and docosahexaenoic acid (DHA) $\left(\mathrm{C}_{22: 6} \mathrm{n}-3\right)$, which are required for many metabolic processes in humans and effectively prevent coronary heart disease (CHD). The concentrations of $\alpha$-linolenic, eicosapentaenoic and docosahexaenoic acids were higher in the milk and cheese from green maize-supplemented animals than in those from the goats fed hay.

The rumenic acid concentrations in milk and cheese were affected by dietary treatments. This c9t11CLA isomer was higher in milk $(0.44 \%$ vs $0.60 \% ; p<0.05)$ and cheese $(0.46 \%$ vs $0.78 \%$; $P<0.01)$ from goats in the experimental group than in the control group. Other authors have reported that the diet - such as one with a high protein level in the dry matter of forage (Czauderna et al., 2010) and supplemental sunflower or soyabean fats (Titi et al., 2011) - can increase the rumenic acid concentration in milk. In addition, the contents of water and fermentable carbohydrates in the forage have significant effects on microbiological fermentation and $\mathrm{pH}$ in the rumen. Rumen $\mathrm{pH}$ has an important role in maintaining a viable environment suitable for Butyrivibrio fibrisolvens (Tsiplakou et al., 2008). Microbial fermentation is influenced by fermentable carbohydrates; it is well known that green maize has a high content of this component, so it creates a favourable rumen environment for rumenic acidproducing bacteria, as reported by Kelly et al. (1998).

In the milk and cheese samples, about $82.6 \%$ $88.2 \%$ of the total conjugated linoleic acid isomers were the c9t11CLA isomer. This is in agreement with the literature reports. Chin et al. (1992) found rumenic acid percentages ranging from $75 \%$ to $90 \%$ in dairy products. Feeding green maize considerably increased the rumenic acid percentage in milk $(82.6 \%$ vs $85.4 \% ; P<0.01)$ and cheese $(83.7 \%$ vs $88.2 \% ; p<0.05)$, respectively. The $t 10 c 12 \mathrm{CLA}$ content of milk and cheese samples did not show any significant differences during experimental period.
The $110 c 12 \mathrm{CLA}$ isomer is produced in the rumen by minor bacterial populations or an alternative biohydrogenation pathway (Tsiplakou et al., 2006).

\section{Conclusions}

There were significant differences in milk composition and fatty acid contents between the two treatments. Feeding green maize resulted in significantly higher concentrations of rumenic acid (c9t11CLA isomer) and n-3 fatty acids such as $\alpha$-linolenic, eicosapentaenoic (EPA) $\left(\mathrm{C}_{20: 5} \mathrm{n}-3\right)$ and docosahexaenoic (DHA) $\left(\mathrm{C}_{22: 6} \mathrm{n}-3\right)$ acids, which are of special interest in terms of promoting human health. Based on our results, it can be concluded that a disadvantageous fatty acid profile due to absence of pasture herbage availability can be improved by the use of a green maize-based diet. Nevertheless, further research is needed to investigate the developing of goat milk EPA and DHA fatty acid contents from other PUFA sources, such as microalga; data on feeding micro-alga supplements are limited, however, although it is well known that the micro-alga species are rich source of PUFAs.

\section{Acknowledgements}

This work was funded by TAMOP Project (TÁMOP-4.2.1.B-11/2/KMR-2011-0003) and Baross Project (OMFB-01174/2006).

\section{References}

Addis M., Cabiddu A., Pinna G., Decandia M., Piredda G., Pirisi A., Molle G., 2005. Milk and cheese fatty acid composition in sheep fed Mediterranean forages with reference to conjugated linoleic acid cis-9,trans-11. J. Dairy Sci. 88, 10, 3443-3454

AOAC, 1990. Association of Official Analytical Chemists, Official Methods of Analysis. $15^{\text {th }}$ Edition. Arlington, VA

Buccioni A., Antongiovanni M., Petacchi F., Mele M., Serra A., Secchiari P., Minieri S., 2008. Effect of dried or green herbage on vaccenic acid and conjugated linoleic acid production during in vitro rumen fermentation. Anim. Feed Sci. Tech. 140, 207-213

Cabiddu A., Decandia M., Addis M., Piredda G., Pirisi A., Molle G., 2005. Managing Mediterranian pastures in order to enhance the level of beneficial fatty acids in sheep milk. Small Ruminant Res. 59, 169-180

Chilliard Y., Ferlay A., Mansbridge M.R., Doreau M., 2000. Ruminant milk fat plasticity: nutritional control of saturated, polyunsaturated, trans and conjugated fatty acids. Ann. Zootech. 49, 181-205

Chin S.F., Liu W., Storkson J.M., Ha Y.L., Pariza M.W., 1992. Dietary sources of conjugated dienoic isomers of linoleic acid, a newly recognized class of anticarcinogens. J. Food Compos. Anal. 5, 185-197 
Couvrer S., Hurtaud C., Lopez C., Delaby L., Peyraud J.L., 2006. The linear relationship between proportion of fresh grass in the cow diet, milk fatty acid composition and butter properties. J. Dairy Sci. 89, 1956-1969

Czauderna M., Kowalczyk J., Michalski J.P., 2010. Effect of a protein level in the diet on fatty acid profile in goat milk. J. Anim. Feed Sci. 19, 211-217

Dewhurst R.J., Shingfield K.J., Lee M.R.F., Scollan N.D., 2006. Increasing the concentrations of beneficial polyunsaturated fatty acids in milk produced by dairy cows in high-forage systems. Anim. Feed Sci. Tech. 131, 168-206

Doreau M., Poncet C., 2000. Ruminal biohydrogenation of fatty acids originating from fresh or preserved grass. Reprod. Nutr. Develop. 40, 201-209

Enser M., Hallet K., Hewett K., Fursey G.A.J., Wood J.D., Harrington G., 1998. Fatty acid content and composition of UK beef and lamb muscle in relation to production system and implications for human nutrition. Meat Sci. 49, 329-341

Galina M.A., Osnaya F., Cuchillo H.M. Haenlein G.F.W., 2007. Cheese quality from milk of grazing or indoor fed Zebu cows and Alpine crossbred goats. Small Ruminant Res. 71, 264-272

Hungarian Feed Codex, 2004. Laboratory Methods and Operations, Vol. 3 (in Hungarian). National Institute for Agricultural Quality Control. Budapest

Ip C., Chin S.F., Scimeca J.A., Pariza M.W., 1991. Mammary cancer prevention by conjugated dienoic derivative of linoleic acid. Cancer Res. 51, 6118-6124

Kelly M.L., Kolver E.S., Bauman D.E., Van Amburgh M.E., Muller L.D., 1998. Effect of intake of pasture on concentrations of conjugated linoleic acid in milk of lactating cows. J. Dairy Sci. 81, 1630-1636

Kuchtik J., Sustova K., Urban T., Zapletal D., 2008. Effect of the stage of lactation on milk composition, its properties and the quality of rennet curdling in East Friesian ewes. Czech J. Anim. Sci. $53,55-63$

Lee M.R.F., Harris L.J., Dewhurst R.J. et al., 2003. The effect of clover silages on long chain fatty acid rumen transformations and digestion in beef steers. Anim. Sci. 76, 491-501
Nicolosi R.J., Rogers E.J., Kritchevski D., Scimeca J.A., Huth P.J., 1997. Dietary conjugated linoleic acid reduces plasma lipoproteins and early aortic atherogenesis in hypercholesterolemic hamsters. Artery 22, 266-277

Novotna L., Kuchtik J., Sustova K,. Zapletal D,. Filipcik R., 2009. Effects of lactation stage and parity on milk yield, composition and properties of organic sheep milk. J. Appl. Anim. Res. 36, $71-76$

NRC, 2007. Nutrient Requirements of Small Ruminants: Sheep, Goats, Cervids and Camelids. National Academic Press. Washington, DC

Pajor F., Galló O., Steiber O., Tasi J., Póti P., 2009. The effect of grazing on the composition of conjugated linoleic isomers and other fatty acids of milk and cheese in goats. J. Anim. Feed Sci. 18, 429-439

Simopoulos A.P., 2004. Omega-6/Omega-3 essential fatty acid ratio and chronic diseases. Food Rev. Int. 20, 77-90

Soryal K.A., Zeng S.S., Min B.R., Hart S.P., Beyene F.A., 2004. Effect of feeding systems on composition of goat milk and yield of Domiati cheese. Small Ruminant Res. 54, 121-129

Titi H.H., Hasan Y.L., Al-Ismail K., Zakaria H., Tabbaa M.J., Abdullah A.Y., Obeidat B.S., 2011. Response of Shami goats and kids to variable levels of soyabean or sunflower oils in diets. J. Anim. Feed Sci. 20, 493-508

Tsiplakou E., Mountzouris K.C., Zervas G., 2006. Concentration of conjugated linoleic acid in grazing sheep and goat milk fat. Livest. Sci. 103, 74-84

Tsiplakou E., Kominakis A., Zervas G., 2008. The interaction between breed and diet on CLA and fatty acids content of milk fat of four sheep breeds kept indoors or at grass. Small Ruminant Res. 74, 179-187

Zan M., Stibilj V., Rogelj I. 2006. Milk fatty acid composition of goats grazing on alpine pasture. Small Ruminant Res. 64, 45-52

Zhang R., Mustafa A.F., Zhao X., 2006. Effects of flaxseed supplementation to lactating ewes on milk composition, cheese yield, and fatty acid composition of milk and cheese. Small Ruminant Res. 63, 233-241 